\title{
Algumas Reflexões Sobre a Arte e a Formação do Psicólogo
}

Some questions about Art and the undergraduate education of Psychologists

Resumo: Este artigo pretende analisar algumas das contribuições da arte para a formação do psicólogo. A partir de uma proposta de estágio supervisionado na área de Psicologia Escolar envolvendo atividades referentes à arte, foi possível constatar mudanças nos estagiários participantes do trabalho em função de um contato aprofundado com música, literatura e artes visuais. Fica patente a necessidade de se pensar a importância da arte na formação pessoal e profissional do psicólogo desde o seu ingresso na universidade. Palavras-Chave: Psicologia, arte, formação de psicólogos.

Abstract: This article aims to analyze some of the contributions of art for the training of psychologists. Through a supervised internship in the area of School Psychology which involved art activities, it was possible to perceive changes in the work of the participating interns due to a profound contact with music, literature and visual arts. The necessity of thinking about the importance of art in the personal and professional training of psychologists since the beginning of their college entrance revealed to be evident.

Key Words: Psychology, art, training of psychologists.

Silvia Maria Cintra da Silva

Professora da Instituto de Psicologia da Universidade Federal de Uberlândia (UFU) - MG, Mestre e Doutora em Educação pela UNICAMP

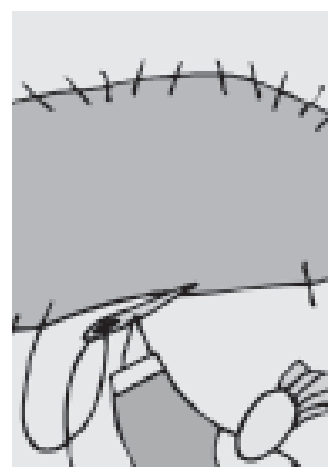

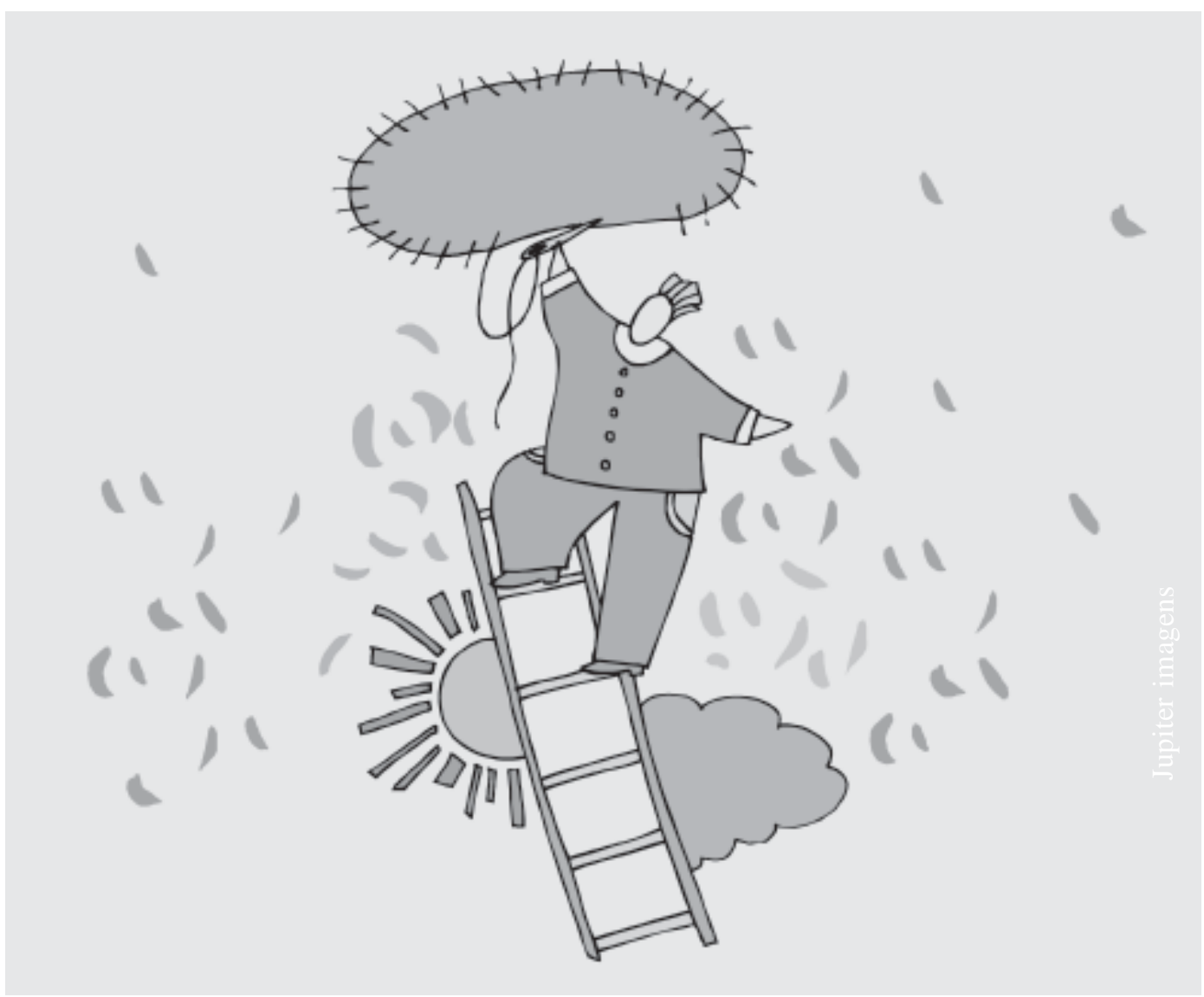

No doutorado, realizamos uma pesquisa (Silva, 2002), que envolveu um estágio supervisionado em Psicologia Escolar, abrangendo crianças com queixas escolares, suas respectivas professoras e mães e tendo, como pano de fundo, a investigação de nossa prática como supervisora no curso de
Psicologia da Universidade Federal de Uberlândia (UFU) - MG. Foram organizados grupos com os segmentos citados e todo o trabalho baseou-se em atividades com música, literatura e artes visuais, durante um ano letivo, em uma escola pública de Uberlândia. 
Os estagiários intervieram na rede de relações formada pelos alunos, mães, professoras e demais funcionários da escola. Para tanto, foi fundamental que eles estivessem na instituição, atentos à amplitude dessa rede e ao cotidiano das pessoas a ela ligadas. Somente dessa maneira puderam compreender o que significava trabalhar, ministrar aulas e estudar naquela escola, procurando evitar julgamentos preconcebidos.

Na literatura voltada para a Psicologia e para a Educação, existem inúmeros trabalhos relacionados à arte, especialmente a arte-terapia ou arte-educação; entretanto, o enfoque aqui apresentado é outro, configurado a partir de um estágio supervisionado em Psicologia Escolar e com uma reflexão sobre como o desenvolvimento de atividades com música, literatura e artes visuais, dialeticamente, também afeta quem organiza e faz acontecer o estágio.

A escolha de nossa pesquisa relacionou-se ao grande interesse pela arte e à nossa percepção das mudanças provocadas em nós mesma por leituras, visitas a museus, audição de músicas. O contato com a obra de arte aproxima as pessoas das características constituintes da condição humana, como alegria, medo, tristeza, angústia, saudade, esperança. Não são essas, também, características do material de trabalho do psicólogo? A esse profissional interessa tudo aquilo que diz respeito aos seres humanos. Outro aspecto a ser considerado é o convite que a obra de arte faz ao fruidor para que ela possa existir. O envolvimento do sujeito, a exigência de que ele entre com sua história de vida, pensamentos, percepções, sentimentos e valores possibilita um avanço nesses mesmos quesitos.

Escritores e poetas têm discutido a condição humana com tal profundidade que suas obras mereceriam leitura atenta por psicólogos e estudantes de Psicologia. Bachelard (1988, p.120) ratifica nossa posição: "Existe um sentido, acreditamos, em falar de análise poética do homem. Os psicólogos não sabem tudo. Os poetas trazem outras luzes a respeito do homem.”

A fruição da obra de arte exige a participação ativa do público. Bronowski (1983) afirma que o artista fornece referências de maneira a despertar o interesse e afetar os sentimentos humanos, mas a pintura ou o quadro só existe se entramos nele e o preenchemos. Esse envolvimento é irreversível: somos capturados pela obra e dela capturamos algo, de acordo com nossas possibilidades, limites, preferências.

Pensamos que, no contato com o fruidor, a obra de arte revela-se polissêmica, possibilitando inúmeros sentidos e leituras simultaneamente e também em momentos diversos. Um poema, uma música, um quadro já conhecidos podem provocar outras reflexões algum tempo depois em função de uma nova leitura, uma nova audição, uma nova observação. Além disso, como Albano (2000, p.3) escreve, "É imprescindível que compreendamos que a arte pode levar-nos para espaços dentro de nós mesmos a que não teríamos acesso de outra maneira.”

\section{Por que Unir Arte e Psicologia?}

A teoria histórico-cultural atribui importância fundamental às interações sociais na formação do psiquismo humano. O desenvolvimento é concebido como o movimento de apropriação de formas culturais mais elaboradas de atividade, sendo que o funcionamento psicológico só pode ser entendido em suas dimensões individual e social. Segundo Vygotsky (1988), os signos criados pela humanidade (como a linguagem, o desenho, os sistemas numéricos etc.) dialeticamente apresentam a capacidade de transformar o funcionamento mental, configurando as funções psicológicas superiores (memória mediada, percepção mediada e outras) e também promovendo alterações qualitativas nas mesmas. Essas funções encontram terreno fértil para seu desenvolvimento no contato com as obras de arte. Acreditamos que, como afirma o citado autor (2001), a vivência estética marca indelevelmente o comportamento humano.

Músicas, livros, pinturas e outras formas de arte são constituídas pela linguagem, mesmo que o artista, inicialmente, não esteja consciente disso ao criar. Ao adquirir forma, a obra de arte exige a participação da consciência do fruidor. Quando o espectador ouve música, por exemplo, toda a atividade mental necessária à apreensão, audição e apreciação tem, como suporte, o signo. Assumindo como pressuposto que a natureza da atividade mental é “social/semiótica” (Smolka, 1997, p. 29), o contato com a obra de arte repercute dialeticamente nos processos mentais envolvidos na fruição, provocando uma expansão nas funções psicológicas como a percepção, a atenção e a memória. A própria polissemia da obra de arte instiga o indivíduo a encontrar novos sentidos a cada leitura.

Pensamos ser possível unir arte e Psicologia também devido a um enorme interesse pessoal e por acreditarmos que o contato com conteúdos referentes à arte possibilita um outro olhar sobre si mesmo e o mundo, podendo conduzir a novos processos mentais ao provocar diferentes formas de pensar e de ver o cotidiano. 
Ao discorrer sobre a obra de arte, Albano (2001, p.3) assinala o

“poder de revelação por ser, ao mesmo tempo, reflexo e espelho. Diante de uma obra, podemos nos observar, ao mesmo tempo que observamos a imagem que se entrega à nossa contemplação. Ao nos emocionarmos com uma obra, passamos a ouvir em nós o eco da mesma verdade que levou o artista a criá-la.”

A autora também afirma que, para que possamos compreender o sentido de uma obra, é necessário permitir que ela nos transforme como transformou o artista. É essa relação dialética que acentua e possibilita a existência da obra de arte no contato com o público.

Vygotsky (1999, $p$. 315) afirma que a arte sempre implica transformação, $e$ enfatiza o seu sentido social ao escrever que "A arte é o social em nós [...]; quando cada um de nós vivencia uma obra de arte, converte-se em pessoal sem, com isso, deixar de continuar social".

1 Os nomes são fictícios.
Vygotsky (1999, p. 315) afirma que a arte sempre social ao escrever que "A arte é o social em nós [...]; quando cada um de nós vivencia uma obra de arte, converte-se em pessoal sem, com isso, deixar de continuar social”. O contato de cada indivíduo com uma música, um poema ou um quadro implica uma apreciação que envolve aspectos cognitivos, afetivos e sociais a partir de seus referenciais histórico-culturais. Para Bronowski (1983), a obra de arte só existe quando a recriamos para nós. Pressupõe, assim, a participação ativa e efetiva do sujeito no processo de fruição. A partir dessa perspectiva, a arte pode oferecer oportunidades preciosas tanto para trabalhos em Psicologia quanto para a formação do psicólogo.

\section{Caracterizando o Estudo}

Metodologicamente, o estudo de caso foi a opção escolhida, configurada a partir da construção dos dados, porque visa apreender o processo focalizado na pesquisa de maneira contextualizada. O que está em jogo é a busca de compreensão sobre o caso apresentado (Rabitti, 1999). Isso significa que o trabalho deve ir além da descrição e que, através de um procedimento de análise, deve ultrapassar a mera apresentação de informações. Para o entendimento da situação pesquisada, é preciso um aprofundamento das reflexões geradas pela investigação. A despeito de uma suposta atipicidade dos estudos de caso, existe sempre a possibilidade de o leitor, instigado pela leitura, fazer generalizações a partir de suas experiências e vivências, por meio de semelhanças e diferenças constatadas no texto (Bogdan e Biklen, 1994).

Para escolher os estagiários, elaboramos um roteiro com oito questões que nos permitissem conhecer os candidatos à seleção a partir dos seguintes aspectos: os motivos pelos quais o aluno gostaria implica transformação, e enfatiza o seu sentido de participar do estágio; experiência anterior em trabalhos com crianças, pais e/ou professores; concepções sobre o fracasso escolar; interesse por cinema, literatura, música, poesia, exposições de arte e possibilidades de relacionar arte, desenvolvimento e aprendizagem. Nas perguntas referentes a atividades culturais, o objetivo era investigar o contato e a busca do discente, por conta própria, por atividades além das indicadas nas disciplinas do curso de Psicologia. Outro critério utilizado para a seleção dos estagiários foi o desempenho geral nas disciplinas Psicologia Escolar e Problemas de Aprendizagem (PEPA) I e II, consideradas pré-requisitos para o estágio. Esse critério restringia a participação de estudantes, solicitando os que estivessem cursando o $9^{\circ}$ período, ou seja, que estivessem no final do curso. Escolhemos cinco alunos: Ana, Lara, Diana, Beatriz e Pedro ${ }^{1}$. O estágio foi organizado da seguinte forma: as estagiárias Ana e Beatriz ficaram responsáveis pelo planejamento e coordenação dos encontros com as crianças (foram organizados dois grupos, em dias e períodos diferentes); os encontros com as professoras ficaram a cargo de Pedro, e Diana e Lara foram as estagiárias incumbidas das mães.

Na escola, havia duas turmas de educação infantil e uma de $1^{\text {a }}$ série sob a responsabilidade da prefeitura, incluindo as professoras. As turmas de $2^{\mathrm{a}}$ a $4{ }^{\mathrm{a}}$ séries, a cargo do Estado, que diziam respeito a esta pesquisa, somavam 278 alunos e quinze professoras, divididas em dois turnos diurnos. Participaram do trabalho oito crianças (divididas em dois grupos), três mães (considerando as participantes mais freqüentes) e oito professoras. Com um grupo de crianças, foram realizados 19 encontros semanais e, com o outro, 17; oito encontros com as docentes e onze com as mães, tendo ambos uma periodicidade semanal. Todos os grupos tinham uma hora de duração, com a possibilidade de ampliação do tempo, de acordo com a demanda dos participantes. Realizamos, com os estagiários, 35 supervisões (de cerca de três horas cada uma), que ocorreram semanalmente, de março a dezembro, acompanhando o calendário da universidade. A carga horária total do estágio foi de 342 horas, tempo que englobou também os momentos destinados à leitura, à preparação de atividades, relatório (escrito) dos encontros e filmagens das crianças.

Os encontros, de caráter optativo, foram organizados em função das necessidades e dificuldades levantadas a partir das citadas observações e entrevistas. Ao longo do ano, o próprio desenvolvimento dos grupos forneceu elementos para a continuidade do trabalho. De forma geral, buscou-se, por meio dos materiais, técnicas e atividades utilizadas (sempre a partir de 
literatura, música e artes visuais), propiciar desafios cognitivos e estéticos que favorecessem aos participantes reflexões a respeito de si, do outro e do cotidiano escolar. Cada grupo apresentou suas especificidades, que foram abordadas de acordo com as necessidades, tendo-se em vista os objetivos mais amplos do trabalho, e de acordo, também, com as características pessoais e profissionais dos estagiários que coordenaram os encontros. Todo o estágio foi pensado, organizado e debatido durante as supervisões, momentos de aprendizado sobre a atuação do psicólogo escolar.

\section{O Registro de Falas e Gestos - Construindo os Dados da Pesquisa}

No delineamento deste estudo, foram utilizadas gravações das supervisões em áudio e vídeogravações dos encontros com as crianças e, na medida do possível, algumas audiogravações de entrevistas com professoras, mães e pais.

Na construção dos dados desta pesquisa, também foram escritos diários de campo, por nós e pelos estagiários, considerados igualmente pesquisadores. A redação dos diários de campo envolveu percepções, sentimentos e pensamentos acerca do estágio, da escola e das supervisões. O relatório final de estágio, exigência do curso de Psicologia da UFU, foi mais um elemento recolhido para análise.

Durante a análise dos dados, ouvimos as 100 horas de supervisão e transcrevemos - com o auxílio de uma colaboradora - integralmente as onze primeiras supervisões (foram 35, ao todo). A análise dos dados privilegiou o enfoque microgenético, que procura abordar minuciosamente as mudanças qualitativas na ação do sujeito, relativas às mediações sociais/semióticas aí envolvidas (Silva, 1998). Nessa abordagem, foram analisados os trabalhos com todos os envolvidos no estágio. Importa analisar não apenas as mudanças acontecidas nos indivíduos participantes da pesquisa, mas também a qualidade das mediações implicadas nessas mudanças.

Por meio da análise microgenética, o psicólogo tem a possibilidade de compreender o sujeito considerando sempre as condições concretas de vida do indivíduo, inserido em um determinado momento histórico. Simultaneamente, também tem oportunidade de olhar para as relações e para os processos mediacionais, constituintes do sujeito, que se estabelecem nos encontros e confrontos interpessoais.

Procuramos investigar mudanças ocorridas nos estagiários a partir do contato com as reproduções de obras de arte, CDs e livros de histórias e com as atividades propostas nas supervisões de estágio, também relacionadas ao campo da arte.

A partir da audição das fitas das supervisões e da leitura do material escrito pelos estagiários, foram analisadas falas do discurso oral (bem como pausas, risos, choro, entonação) e palavras do texto escrito, tendo em vista a apreensão dos sentidos configurados no trabalho realizado na escola e nas supervisões, bem como a constatação de modificações geradas na pesquisa.

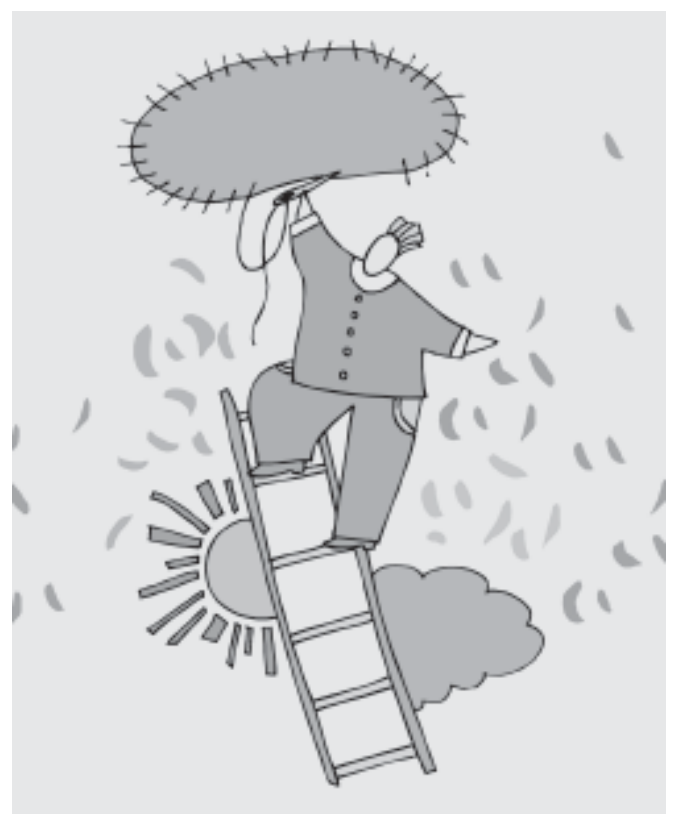

\section{As Supervisões}

As supervisões ocorreram semanalmente, em um período de três horas. Embora um encontro fosse sempre muito diferente dos outros, algumas atividades mais rotineiras delinearam o cotidiano, como discussões teóricas, relatos e planejamento dos trabalhos realizados na escola.

Inicialmente, apresentamos-lhes brevemente as linhas gerais do trabalho e de nossa pesquisa, nosso estilo de supervisão, alguns livros e textos que seriam fundamentais para o trabalho na escola, e colocamo-nos à disposição para contatos individuais com os estagiários, caso fossem necessários. Os textos que consideramos leituras essenciais para o estágio foram lidos por todos os estagiários. No decorrer do trabalho, fomos indicando novas leituras, de acordo com as requisições feitas pelos estagiários e com as necessidades específicas de cada um dos segmentos abordados (crianças, mães e professoras). Procuramos discutir com eles o que gostaríamos que fizessem no estágio que seria realizado na escola: apreciar reproduções de obras de arte,
2 Os estagiários leram, por exemplo, Buoro, A. B. O Olhar em Construção - uma Experiência de Ensino $e$ Aprendizagem da Arte na Escola. São Paulo: Cortez, 1996. Colit, J. O que É Arte. 8. ed. São Paulo: Brasiliense, 1987. Collares, C. A . L. \& Moysés, M. A. A. Preconceitos no Cotidiano Escolar: Ensino e Medicalização. São Paulo: Cortez: Campinas: Unicamp: Faculdade de Educação/ Faculdade de Ciências Médicas, 1996. Machado, A. M. \& Souza, M. P. R. Psicologia Escolar: em Busca de Novos Rumos. São Paulo: Casa do Psicólogo, 1997. Patto, M. H. S. A Família Pobre e a Escola Pública: Anotações Sobre um Desencontro. Psicologia USP, S. Paulo, 3 (1/2), 1992, pp. 107-121. 
livros e músicas; ouvir e contar histórias e poemas, pensar sobre o que viam e ouviam. A partir das reflexões desencadeadas por esse material, buscariam maneiras de selecionar e organizar atividades para os encontros com as crianças, as professoras e as mães.

Trabalhamos o olhar e o ouvir através de algumas reproduções de obras de arte e músicas. Uma reprodução bastante discutida foi "Las Meninas", de Velázquez, com apoio do artigo homônimo de Foucault (1995). No dia em que conversamos sobre essa obra, Pedro comentou:

"Eu quero saber porque até agora ninguém pediu o intervalo... Olha como mobiliza mesmo, hein? Eu só quero saber por que até agora não pediu o intervalo? Olha que legal, vai ser muito jóia trabalhar com os professores também com arte".

"Eu quero saber porque até agora ninguém pediu o intervalo... Olha como mobiliza mesmo, hein? Eu só quero saber por que até agora não pediu o intervalo? Olha que

legal, vai ser muito jóia trabalhar com os professores também com arte".

3 Os trechos em itálico referemse à transcrição de falas ou de relatos escritos pelos estagiários.

4 Diana precisou afastar-se do estágio por motivos pessoais e não participou de todas as atividades realizadas na escola e nas supervisões.
Para podermos aprofundar alguns aspectos abordados no estágio, algumas vezes solicitamos aos estagiários que recordassem suas histórias escolares, como as experiências agradáveis e práticas disciplinares, as vivências de sucesso e fracasso. Olhar para o outro a partir de sua própria condição humana pode ajudar o profissional a pensar sobre sua atuação a partir de parâmetros mais realistas. Observar os nossos próprios sentimentos, despertados durante o trabalho recomendávamos - é importante, pois é uma maneira de entender o que o outro está querendo nos dizer, para além das palavras; também é importante para aprendermos a lidar com esses sentimentos gerados no encontro com o outro.

A distribuição dos grupos entre os estagiários foi orientada pelo desejo e interesse de cada um deles pelo respectivo público e trabalho a ser realizado. O estágio baseou-se em uma visão prospectiva do desenvolvimento humano, pois, ao trabalharmos com atividades que não faziam parte do cotidiano daquelas pessoas, buscamos desafiá-las cognitiva, afetiva e esteticamente. Algumas atividades eram totalmente inéditas para elas e consideramos o que poderiam aprender e desenvolver para além das condições atuais. Não se trabalhou com conquistas consolidadas (Oliveira, 1995), o que geralmente ocorre no cotidiano escolar. O foco principal foram as mudanças que as tarefas, envolvendo artes visuais, música e literatura, poderiam provocar.

Pedro escreveu pequenos textos e poemas referentes ao que estava vivenciando no estágio, chegando a utilizar alguns deles nos encontros com as professoras. Ana brincou com lápis, tintas, papéis, livros e músicas ao preparar as atividades que seriam desenvolvidas no grupo. Motivada pelo contato com reproduções de artistas que até então desagradáveis partilhadas com professores, as desconhecia, realizou desenhos e colagens em seu caderno de supervisão (ou diário de bordo, como ela o chamou), elaborando uma espécie de relato gráfico. Isso mostra, além de seu entusiasmo e envolvimento no trabalho, que também foi afetada por ele.

Além dos assuntos pertinentes ao estágio, outros temas surgiram durante os nossos encontros, como comentários sobre a formação do psicólogo, o contexto socio-político-econômico-educacional brasileiro, notícias veiculadas pela mídia impressa e televisiva, programas de televisão, eventos da cidade de Uberlândia e outros. Durante o ano, à medida que líamos novos textos pertinentes ao trabalho desenvolvido na escola e artigos de jornal relativos à educação, nós os introduzíamos na supervisão para a leitura dos estagiários e para posterior discussão. Sugerimos diversos filmes - de cineastas que questionam nossas formas de olhar e tecemos breves comentários sobre o nascimento do cinema, sobre alguns diretores e movimentos cinematográficos, pois acreditamos que o cinema pode possibilitar reflexões fecundas sobre a vida humana, de maneira geral, e sobre a própria estética e narrativa dos filmes.

\section{Recursos Materiais e Técnicos Utilizados nas Supervisões e no Estágio}

Os livros de histórias e de poemas, os CDs e as reproduções de obras de arte foram utilizados nos três grupos coordenados pelos estagiários - o das crianças, das mães e das professoras - e também nas supervisões. A escolha desse material foi guiada por nossas experiências e preferências pessoais, mas eles ficaram à vontade para utilizar outros textos, poemas, músicas e reproduções de que gostassem. Outro aspecto pensado na seleção do material foi a facilidade de acesso e a viabilidade de aquisição do mesmo pela escola, após o término do estágio, se houvesse interesse.

Durante as supervisões, o material foi apresentado e colocado à disposição dos estagiários, para ser usado não apenas neste estágio, mas também em outros, e/ou para ser utilizado em outras situações, por interesses particulares. É curioso que, durante o ano, outros alunos do curso de Psicologia vieram solicitar-nos o empréstimo de alguns livros e CDs, atraídos pela divulgação feita pelos estagiários.

Cada estagiário responsabilizou-se pela organização dos grupos com o qual iria trabalhar e o interesse pessoal de Pedro, Ana, Beatriz e Lara ${ }^{4}$ serviu como parâmetro para a seleção de atividades e materiais para o trabalho na escola. Um ponto sobre o qual insistimos muito foi que todo o 
material utilizado deveria ser, primeiramente, intensa e exaustivamente explorado pelos próprios estagiários. Sugerimos que adotassem "Gramática da Fantasia”, de Giani Rodari (1982), como livro de cabeceira, repleto de idéias interessantes para o estágio. Diana disse que era como um livro de pensamentos, "pra ler todo dia”.

Propusemos algumas atividades de pintura, recorte, colagem e desenho aos próprios estagiários, para que eles pudessem, nesse fazer, experimentar cores, texturas, técnicas e também pensar sobre as atividades e o impacto destas junto aos grupos de trabalho na escola. Beatriz escreveu, em seu diário de campo, sobre uma dessas experiências:

"Hoje a supervisão foi na casa da Silvia e foi muito especial e diferente. Fizemos atividades que são sugestões para o trabalho com as crianças. É muito legal lembrar-se dos tempos de criança; tinta, giz de cera e cola têm cheiros que remetem à infância. Além de aprender novas técnicas, saí da supervisão lembrando-me de coisas boas. A escola, velhos amigos que não estão mais comigo e que são impossíveis de ver, senão quando se sente o cheiro de ser criança."

A exploração do material feita por Ana, Lara, Pedro e Beatriz foi fundamental para maior conhecimento a respeito do mesmo e posterior seleção para utilização no estágio. Era preciso apresentar o material de forma que eles pudessem observá-lo, tocá-lo e senti-lo, trazendo-o para a própria vida. Apenas um mergulho nos livros, reproduções de obras de arte e nas músicas possibilitaria um contato efetivo, que provocasse um impacto nos estagiários, impacto necessário para dar sentido ao trabalho que seria desenvolvido por eles.

Pedro sentiu-se muito à vontade no planejamento das atividades e utilizou as perguntas da pesquisa e suas preferências pessoais para selecionar o material para os encontros. Além do que oferecemos, levou textos de Rubem Alves, poemas de Carlos Drummond de Andrade e de Vinícius de Moraes, músicas de Chico Buarque, Gonzaguinha, Ivan Lins, Geraldo Vandré e reproduções de Camile Pissaro. Também trabalhou com poemas que escreveu, inspirado pelo próprio estágio.

O envolvimento dos estagiários com as reproduções de obras de arte, CDs e livros de histórias, material trabalhado no estágio e nas supervisões acabou conduzindo a pesquisa para um caminho que não havia sido originalmente pensado. Ao longo do ano, houve um contínuo interesse e entusiasmo por todo o material que estava sendo empregado, como um enamoramento. Nós não havíamos previsto o arrebatamento que esse material poderia provocar em Ana, Beatriz, Lara e Pedro, nem as mudanças desencadeadas nos estagiários pelo contato com o mesmo. Isso foi imprescindível para que, na interlocução com as crianças, pais e professores, o emprego de música, literatura e artes visuais não soasse de maneira artificial, mas como algo que efetivamente fizesse sentido para os estagiários.

O progressivo e contínuo contato com o material acima citado gerou reflexões baseadas em contatos anteriores com o mundo da arte. Diana e Ana recordaram-se de experiências vividas na infância, em aulas de Educação Artística e oficinas organizadas nas escolas em que estudaram e que as marcaram profundamente. Lara e Diana lembraram-se que, antes de entrar na faculdade, ouviam músicas e liam poemas com mais freqüência, o que foi deixando de ocorrer ao longo do curso.

Os estagiários começaram a levar para a supervisão livros, recortes de jornal e notícias de exposições de arte. Pedro passou a gravar alguns filmes transmitidos na televisão (por canais pagos) que considerava interessantes, a fim de emprestá-los para o grupo.

Houve mudanças em relação ao próprio material utilizado no estágio. Na primeira vez em que ouviu "Canções Curiosas", Pedro disse que não havia gostado: "São músicas que eles mesmos compuseram, não são aquelas tradicionais... é um estilão bem MPB”. Embora ele apreciasse a música popular brasileira, o referido CD provocou-lhe um estranhamento, pois estava acostumado a um outro tipo de música para crianças. Algum tempo depois, ele voltou ao assunto, dizendo a Lara: "Você é custosa, você me fez gostar daquele CD que eu não gostava”. Entusiasmada com as músicas, ela havia conseguido despertar o interesse do colega, apresentando-lhe uma outra maneira de ouvi-las. Diana contou, animadamente, que estava contagiando alguns colegas de curso: " $E$ u fico ouvindo no carro; aliás, o povo deve achar que eu sou louca, porque eu saio ouvindo 'Castelo Rá-TimBum'... Eu estou propagando todas as músicas”.

Beatriz conheceu um artista plástico em Goiânia e conversou com ele a respeito do estágio. Em visita a essa mesma cidade, foi a uma exposição de xilogravuras de Salvador Dalí. Entusiasmada, explicou a técnica para o grupo e contou que acompanhou a visita monitorada de um grupo de crianças, aproveitando para observar as suas reações e comentários.

Em uma viagem, Pedro precisou aguardar o vôo no aeroporto de São Paulo. Havia uma exposição de esculturas e a artista estava presente no local. 
Ele aproximou-se, conversou a respeito da obra e sobre o estágio. Na supervisão, disse que, se isso houvesse ocorrido há um ano, sequer teria parado para observar a exposição.

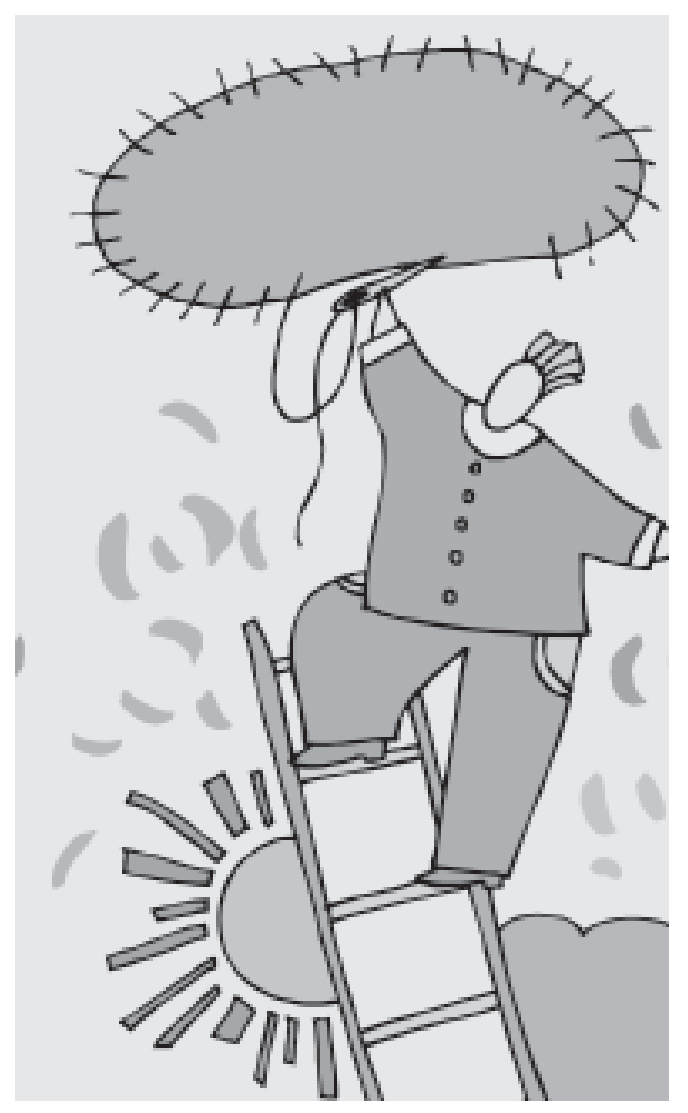

Os interesses dos estagiários não ficaram restritos aos limites do estágio. Eles ouviram todos os CDs, não apenas para utilização no trabalho mas também para apreciação pessoal. Uma criança, prima de Beatriz, ao visitá-la, ouviu "AArca de Noé" e falou: "Até que enfim alguém comprou um $C D$ bom nessa casa!”

Lara, que desde o primeiro momento em que viu reproduções de Gustav Klimt apaixonou-se pelo pintor (em uma aula da disciplina PEPA II, sobre o desenho da criança), pediu para ficar responsável pela apresentação da vida e obra do mesmo. Enquanto mostrava ao grupo o material que havia preparado, lançava algumas perguntas: "O que que vocês percebem nessa mulher aqui ?”, "Perceberam a diferença deste Klimt e desse Klimt?”, destacando as influências sociais sobre a produção do artista. As biografias de alguns dos artistas estudados, como Paul Cézanne, Paul Klee, Gustav Klimt, Henri Matisse, Piet Mondrian, Pablo Picasso e Candido Portinari, despertaram questionamentos e reflexões sobre arte, apreciação, processo criativo e influências culturais.
Inicialmente, as biografias e algumas obras foram apresentadas e discutidas nas supervisões, para que, posteriormente, os estagiários selecionassem e organizassem os trabalhos nos grupos, orientados por suas preferências pessoais. Beatriz disse que havia ficado impressionada com as atividades políticas de Portinari, totalmente desconhecidas para ela. Ana comentou que, ao se conhecer o artista, a obra passa a ser vista de uma outra forma: "Porque o próprio pintor, ele tá dentro de uma sociedade, num contexto histórico...". Beatriz acrescentou: "E ele não vai ficar neutro".

O contato com a obra de alguns artistas, como Gustav Klimt e Piet Mondrian, anteriormente desconhecidos, despertou curiosidade e delineou predileções.

A série “Jazz”, de Henri Matisse, por exemplo, causou bastante surpresa pela técnica (recorte e colagem), que lhes pareceu pouco usual. A partir desse artista, o segundo a ser focalizado, o grupo começou a explicitar suas preferências, atitude fundamental para poderem pensar sobre as obras, o que pode ser verificado no comentário de Ana sobre Matisse: "Eu vi, eu gostei; eu gosto dessas cores fortes".

Com o passar do tempo, começaram a estabelecer comparações entre os artistas pesquisados, como fez Lara, a respeito de algumas reproduções de Cézanne: "Comparando com o Klimt, essas mulheres... não têm muita sensualidade, elas são simples”. Reproduções, músicas, histórias e poemas foram configurando sentidos relacionados às vivências de cada um dos estagiários.

Como os próprios estagiários se lembraram, com a entrada na faculdade, acabaram abandonando livros de literatura, poemas e músicas em função da exigente rotina universitária. Será que se, desde o início do curso de Psicologia, houvesse um incentivo, através de programas criados com tal finalidade, para que os alunos continuassem (ou começassem) a desenvolver interesse e aprofundamento sobre música, literatura e artes visuais, esse quadro seria diferente?

Pelas respostas apresentadas na seleção do estágio, Pedro, Beatriz, Diana, Lara e Ana já demonstravam um interesse por arte, fato fundamental para que o contato com o conteúdo que lhes apresentamos partisse dessa simpatia inicial.

\section{Atividades e Materiais não Usuais} na Supervisão

Consideramos algumas das atividades desenvolvidas com os estagiários bastante inusitadas, porque foram 
incluídas pela primeira vez em um estágio que supervisionamos e por não serem prática corrente no curso de Psicologia da UFU. Uma delas foi o incentivo a maior contato com o cinema. Existe um evento mensal na cidade de Uberlândia chamado "Projeto Pré-Estréia", que traz filmes que não entram no circuito comercial, por apresentarem uma diferenciação em relação a este, seja pela narrativa, seja pelo tema abordado, fazendo parte do chamado "cinema de arte". Em algumas ocasiões, quando os filmes são brasileiros, as organizadoras do evento procuram trazer, para um debate com a platéia, alguma pessoa diretamente relacionada à película, como o diretor, o produtor ou algum ator.

Para incentivar os estagiários a terem contato com esse tipo de produção cinematográfica, inicialmente, nós os avisávamos sobre os títulos em cartaz; depois, a iniciativa de assistir aos filmes partiu deles próprios. Na supervisão seguinte à exibição, fazíamos comentários a respeito do filme e do debate, quando este ocorria.

Outra atividade inédita foi a presença do artista plástico Henrique Lemes em uma das supervisões. Nascido em Uberlândia e radicado desde 1994 em Bremen, na Alemanha, estava no Brasil na época do estágio, e, gentilmente, aceitou nosso convite para falar a respeito de seu trabalho. Contou-nos a respeito de sua formação, seu trabalho com xilogravura, o processo de criação, a relação com o público, a crítica e o mercado de artes plásticas, e de como é ser um artista brasileiro na Alemanha. Henrique levou todas as gravuras e esculturas que havia trazido para uma exposição e pudemos apreciá-las e perguntar-lhe a respeito das mesmas.

Como os estagiários já haviam lido e discutido a respeito de alguns artistas, demonstraram muita curiosidade sobre Henrique e sua obra. Foi uma experiência bastante incomum e que proporcionou aos estagiários uma outra visão sobre a arte, de forma geral, e sobre o trabalho de um artista contemporâneo.

Desde o início do ano, havíamos combinado com os estagiários que, se houvesse alguma grande exposição em São Paulo, faríamos uma excursão, aproveitando também para passear um pouco por essa cidade, praticamente desconhecida para eles. Freqüentar museus é uma atividade que pode ser extremamente educativa (Buoro, 1996; Thistlewood, 1997; Ott, 1997), pois o contato com a obra original, o espaço museológico e os rituais presentes na apreciação favorecem uma ampliação do repertório estético e uma compreensão maior sobre os conceitos de arte.
Em outubro, fomos a São Paulo. Chegamos à avenida Paulista antes do horário de abertura do Museu de Arte de São Paulo (MASP) e sugerimos que fôssemos até a Livraria Cultura. No MASP, vimos “Picasso, Anos de Guerra - 1937-1945". Depois do almoço, fomos ao Banco Real ver a exposição "O Brasil e os Holandeses”; em seguida, à Galeria da FIESP, onde vimos "Entre, a obra está aberta”, de Amélia Toledo. Finalizando a maratona, no Parque da Luz vimos "Esculturas Monumentais Européias”. Aproveitamos para passar pela Estação Júlio Prestes e conhecer a Sala São Paulo que, infelizmente, estava fechada. Emoldurada pelos fantásticos vitrais da estação, vimos a última exposição - “Mapa Cultural Paulista” -, um panorama com obras de artistas de inúmeras cidades do Estado de São Paulo.

A viagem foi inesquecível. Pedro repetiu diversas vezes “Eu vi Picasso!”, e recorto um trecho de seu relato escrito a respeito da experiência:

"Picasso é um toureiro de emoções. Não se sai o mesmo após Picasso. Os anos de Guerra passaram por ele e ele passou por nós deixando vestígios inapagáveis. A Guerra guerreou contra ele e ele guerreia contra nós. (...)

As 'Esculturas do Mundo’passaram por nós, não lhes somos indiferentes. Como ser indiferente a uma tão grande linguagem feita com palavras tão nítidas que são os tamanhos enormes de expressões culturais? Amélia Toledo abriu a sua obra. Entre quem quiser! Como não entrar, com tamanha suavidade? Ver o Brasil-Holandês levou-nos a uma história malcontada. Pouco se fala, pois quem ficou para contar a história são os supostos ${ }^{5}$ vencedores. Aliás, vencedor de quê!?. Picasso abriu uma história a ser contada. Como fechar a gestalt de Picasso? Como encerrar Picasso?”.

O texto de Lara também mostra o impacto da viagem e ilustra tanto o enamoramento pela arte, no olhar dirigido aos pormenores das obras apreciadas, quanto a atenção da estagiária à cidade, aos edifícios, ao contexto mais amplo em que as obras estavam inseridas; indica alterações em seus sentimentos, percepção, memória e pensamentos e atesta a importância da arte para a formação do psicólogo:

"Ir para São Paulo parecia algo irreal. Conhecer Picasso ao vivo foi inacreditável. Eu vi um Picasso; não, várias obras de Picasso ao vivo, a menos de um metro de distância!!!

A viagem foi cansativa mas inesquecível. São Paulo é uma cidade linda. Falavam da poluição, do caos urbano, da violência, etc... A impressão que eu fiquei foi: modernidade, vida, arte. Foi uma das melhores
As 'Esculturas do Mundo' passaram por nós, não lhes somos indiferentes. Como ser indiferente a uma tão grande linguagem feita com palavras tão nítidas que são os tamanhos enormes de expressões culturais? Amélia Toledo abriu a sua obra. Entre quem quiser! Como não entrar, com tamanha suavidade? Ver o Brasil-Holandês levounos a uma história malcontada. Pouco se fala, pois quem ficou para contar a história são os supostos vencedores. Aliás, vencedor de quê!?. Picasso abriu uma história a ser contada. Como fechar a gestalt de Picasso? Como encerrar Picasso?".

5 Grifos do estagiário. 
tardes de sábado que eu passei. Primeiro foi a exposição de Picasso. Quanta angústia, caos, tristeza. Tanta coisa, e eu não vi quase nada. Não sei explicar o que vi; o que senti foi emoção, algo que cresce, não é triste, nem alegre. É uma ansiedade, indignação diante de tanta genialidade, inteligência inigualável. Como homem, Picasso é cruel com as mulheres, mas é um gênio. Cada obra despertou em mim sentimentos inomináveis.

Depois os holandeses. Nosso país mapeado e retratado com formas muito originais e detalhadas. Cada mapa minuciosamente traçado. Cada tela que demonstrava a admiração dos estrangeiros por nosso país. E o prédio do banco. Uma belíssima obra de arquitetura. Agradável local que acredito agradar e satisfazer vários clientes.

A arte contemporânea de Amélia Toledo me deixou sem ação. Não sabia o que fazer, mas fiz um pouco do que achei possível. Foi necessário um pouco de coragem. Será que pode, será que não? Será que eu deixarei marcas? Será que é isso que ela queria, ou será que ela previa mais ou menos as nossas ações? Não sei...

No Parque da Luz mais e mais... não sei o quê. Essas esculturas enormes me fizeram sentir o que sou. Mas eu descobri, se eu quiser, posso me transformar. Meus atos, meu trabalho pode me fazer mais. O que estes artistas fazem, os torna imortais. O efeito das obras muda o mundo das pessoas que permitem. Felizes estes que dão permissão.

Sou um pouco 'melhor' hoje. Muita coisa em mim mudou e está mudando. Hoje eu vivo mais, porque algo pede mais e mais em mim. É uma inquietação que atormenta e uma acomodação satisfatória ao mesmo tempo. Confuso, né? Para entender, sim. Para crescer, não. Não deixa de ser difícil e bom”.

Em ambos os textos, a palavra mudança está presente. Outras palavras sugerem, ainda, que o contato com as obras de arte adquiriu o caráter de uma epifania: linhas, formas, volumes, espaços, cores e luzes provocaram reverberações, traduzidas em modificações nos sentimentos, pensamentos e gestos. Lara fala de inquietação e de acomodação, movimentos imprescindíveis ao desenvolvimento humano.

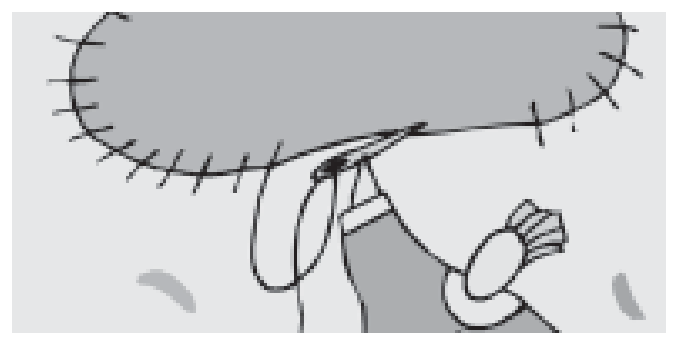

Nessa viagem, passamos do século XVI ao XX, e tivemos contato com as mais variadas produções, diversos tipos de suporte e espaços de exposição, o que provocou impactos estéticos, cognitivos, afetivos, sociais. Enfim, foi uma grande experiência em nossas vidas, uma viagem para dentro de nós mesmos, algo que a arte pode proporcionar de maneira contundente.

\section{A Constatação das Mudanças Ocorridas}

A proposta desenvolvida na escola mostrou-se bastante promissora. Considerando-se o tempo do estágio, as alterações observadas nas crianças, nas mães e nas professoras, no sentido de um maior interesse pelo conhecimento de maneira geral e pelas diversas linguagens artísticas, referendam a viabilidade de um trabalho em Psicologia Escolar baseado em atividades envolvendo música, artes visuais e literatura. Vemos a arte como importante veículo para que as crianças, professoras, pais e mães repensem o contexto educacional e sua realidade de assujeitamento, buscando construir ações emancipatórias.

Algumas mudanças verificadas nos gestos, falas e ações dos estagiários surgiram ao longo do ano, evidenciadas durante as supervisões. Alterações, denunciadas em falas como as abaixo citadas, mostram transformações ocorridas na percepção dos estagiários. Diana lembrou que, quando Lara apresentou Klimt, disse que passou a reconhecer trabalhos desse artista em outros contextos, e perguntou: "Será que isso vai acontecer comigo, em relação a Cézanne? E assim, olhando pro quadro (reprodução de um auto-retrato de Cézanne que havíamos levado), eu sei até em que fase ele pintou isso aqui (ri)".

A estagiária admirou-se ao perceber que havia reconhecido o auto-retrato do artista antes que citássemos a autoria. Isso também mostra a irreversibilidade do conhecimento, denunciada na mudança do olhar.

Lara comentou que havia mostrado algumas reproduções de Renoir para o namorado, perguntando o que ele pensava e sentia a respeito. A estagiária percebeu que ele não estava acompanhando as mudanças que via em si mesma. Ele não estava tendo as mesmas oportunidades que ela de conhecer reproduções de obras de alguns artistas, detendo o olhar sobre elas e podendo pensar a respeito de suas impressões e sentimentos.

No mesmo dia em que Pedro apresentou informações e reproduções de Mondrian, Diana 
se surpreendeu, quando, à tarde, ao chamar uma cliente (de um estágio em Psicologia Clínica) na sala de espera, observou que esta usava uma calça azul, uma camiseta branca e estava encostada em uma almofada vermelha. Ao ver tal cena, a estagiária pensou: "Gente, um quadro do Mondrian na minha frente!”.

Lara citou uma teoria existente em Psicologia Social sobre mudanças ocorridas na percepção em função dos referenciais pessoais de cada um: "Eu estou desse jeito, parece que onde eu vejo tem arte: no jornal, na televisão, não é?’.

Esses dois exemplos evidenciam as modificações ocorridas na percepção das estagiárias não apenas em função do contato com reproduções de obras de arte, mas também com as atividades realizadas ao longo das supervisões e do próprio estágio. Segundo a teoria histórico-cultural, percepção e linguagem são funções psicológicas que mantêm um estreito vínculo, pois o sujeito realiza recortes no mundo em que vive por meio da palavra, percebendo esse mundo sempre de maneira contextualizada (Smolka, 1997). O contato com diversas imagens desencadeou reflexões que, por sua vez, provocaram transformações nos processos perceptivos.

No final do ano, ao se referir ao estágio, Pedro disse que "abriu um leque..., de visão, de trabalho, de tudo, tudo!” Ana falou que adorou fazer o estágio, aprendeu muito e trabalhou com algo de que gostava muito, que era a arte. Também disse que adorou ter conhecido os pintores.

Beatriz também gostou, aprendeu coisas não apenas relativas à Psicologia Escolar mas à vida, e considerou muito bom começar "a pensar diferente do que é passado... pensar por mim mesma”. Lara falou que "O processo é muito mais lento, árduo e doloroso do que eu pensava”. Ficou emocionada com as pessoas que participaram dos encontros e sentiu que cresceu pessoal e profissionalmente. Estudar um pouco sobre arte, ouvir músicas e ver filmes, atividades às quais não tinha acesso antes, também fizeram-na crescer: "Passei a entender um pouco mais sobre as pessoas, o mundo e suas relações”.

Beatriz, Lara, Ana e Pedro deram o melhor de si. Envolveram-se não apenas com os seus respectivos grupos, mas com todo o projeto desenvolvido na escola e conseguiram, efetivamente, realizar um trabalho de Psicologia Escolar. Isso não significa que não tenha havido falhas, incluindo aquelas que poderiam ter sido levantadas e resolvidas durante a supervisão, talvez até porque só pudemos pensar mais detalhadamente no estágio como um todo ao debruçar-nos sobre os dados da pesquisa de forma mais minuciosa.
Considerando o curto espaço de tempo que os estagiários tiveram para metabolizar a descoberta das histórias, das músicas, dos artistas e de algumas obras e o empenho pessoal na realização de todas as atividades do estágio, creio que foi feito o possível, tendo em vista as condições cognitivas e afetivas de cada um deles, as circunstâncias do trabalho realizado na escola e as oportunidades apresentadas nas supervisões.

Tanto Ana quanto Beatriz destacaram que o estágio poderia ajudá-las em qualquer outra área da Psicologia e na vida, de maneira geral. Esse é um ponto importante para nós, pois mostra uma coerência com a nossa posição quanto à formação do futuro psicólogo. A mediação do supervisor, ao incidir sobre aspectos básicos para a atuação profissional, como a preocupação com uma conduta pautada pela ética, esforço constante por um respaldo teórico consistente e cuidado com a formação pessoal, torna-se válida para o trabalho do psicólogo, independentemente da área da Psicologia em que este vá atuar.

No relatório final, Beatriz escreveu que "O trabalho com arte mudou minha forma de ver as coisas; é impossível passar pelas experiências que passamos e sair da mesma forma". Relatou também que aprendeu a ver as coisas com "olhos mais atentos, olhos diferentes...". A expressão “olhos atentos" referese a um olhar mais ampliado, mas envolve também uma escuta mais sensível, atenta ao outro e esses constituem aspectos imprescindíveis para a atuação profissional.

Em uma das últimas supervisões, Lara afirmou que o psicólogo teria que estar mais aberto, pois lida "com o inesperado o tempo inteiro. Tem que estar mais aberto pra coisas fora do convencional”. Nesse sentido, acredito que a arte pode contribuir para isso, desde que a pessoa esteja disposta a conhecer e a enfrentar o desconhecido. Como a própria estagiária escreveu no texto sobre a viagem a São Paulo, "Felizes estes que dão permissão", que se permitem entrar em contato com algo novo, inusitado.

Na formação profissional, merece atenção especial a construção de um olhar e de uma escuta atentos, ampliados e aprofundados ao contexto em que o profissional está inserido. Para isso, acreditamos que a arte tem um imprescindível papel desde a entrada do futuro psicólogo na academia:

"Um lastro de filosofia, artes e sensibilidade, comum a todos os cursos de uma universidade, certamente redundaria em ganhos para todos, em especial para o profissional em formação, que entenderia ser o seu conhecimento específico tão-só um dos componentes que constituem uma sabedoria de vida abrangente (Duarte-Jr., 2001, p.203).”
Um lastro de filosofia, artes e sensibilidade, comum a todos os cursos de uma universidade, certamente redundaria em ganhos para todos, em especial para o profissional em formação, que entenderia ser o seu conhecimento específico tão-só um dos componentes que constituem uma sabedoria de vida abrangente

Duarte-Jr. 
O impacto da arte na vida dos estagiários aponta um novo caminho em Psicologia Escolar, relacionado ao investimento na formação do psicólogo que deve acontecer logo na entrada do estudante na universidade.

Referimo-nos, especificamente, à formação do psicólogo escolar porque a pesquisa envolveu essa área da Psicologia. Entretanto, acreditamos que as reflexões aqui apresentadas podem ser válidas para a formação do psicólogo, de maneira geral, independentemente do campo de atuação. Algumas posturas e questionamentos provocados pelo contato com a arte são fundamentais para esse profissional, como o enfrentamento e a abertura diante do novo e do diferente, a apreciação fundada no conhecimento efetivo do objeto, a criatividade despertada pelo contato com diversas obras, técnicas e materiais que não os usualmente vistos, lidos e ouvidos.

Percebemos que, se o aluno, ao entrar na faculdade, tem algum interesse por atividades ligadas à arte, ao longo do curso vai deixando-as de lado por não considerá-las importantes para a sua formação. Apenas alguns alunos continuam lendo poemas, vendo filmes (que fogem do padrão hollywoodiano) e ouvindo músicas, sendo que isso deveria ser algo constante, presente durante os cinco anos da graduação. Somente dessa maneira é que se pode pensar em desenvolvimento pessoal, e não apenas profissional. Um estágio como o aqui apresentado mostra-se como uma possibilidade diferenciada para se pensar sobre aspectos fundamentais para o desenvolvimento do ser humano, como criatividade, imaginação, cognição e afetividade.

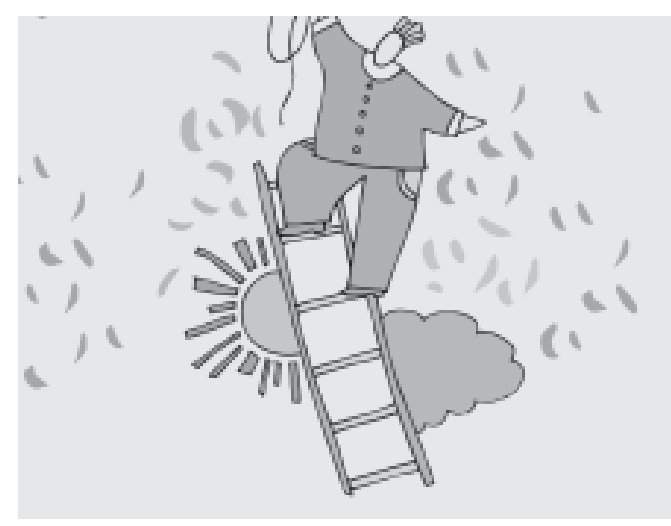

Reconhecemos que esse estágio é um trabalho que exige condições excepcionais, tanto pela carga horária quanto pelo material utilizado, como os CDs, os livros de história, as reproduções de obras de arte, as leituras indicadas e as atividades que hoje vemos como imprescindíveis, como visitas a museus, contato com artistas contemporâneos e o
“Projeto Pré-Estréia”. Sabemos que nem todos os supervisores de estágio em Psicologia Escolar teriam disponibilidade para conduzir um estágio semelhante. Entretanto, este não é um modelo a ser implantado. A generalização mostra-se restrita devido às próprias características do estudo de caso, e cada leitor poderá fazer os recortes que forem ao encontro de sua vivência pessoal e profissional.

Enfatizamos que este trabalho só pôde acontecer porque o contato e o envolvimento dos estagiários com os CDs, livros de história e reproduções de obras de arte, e os vínculos afetivos estabelecidos entre as pessoas participantes da pesquisa constituíram uma trama fortemente entrelaçada. Sabemos que a ligação construída entre os estagiários e nós foi perpassada por afeto, e isso precisa ser explicitado. Todo e qualquer processo de aprendizagem passa pela figura do mediador, geralmente idealizada pelo aprendiz. Nosso entusiasmo pelo trabalho realizado na escola e pela arte não pode ser esquecido para o entendimento dos processos de aproximação de Lara, Ana, Beatriz, Diana e Pedro dos citados materiais e para a compreensão da maneira como cada um deles se apropriou das formas de ação relacionadas à nossa mediação (configurada, nas supervisões, pelos livros, músicas, imagens e por todas as experiências ali vivenciadas). Nesses contatos, a aprendizagem foi suficientemente significativa para incentivar um interesse maior pela arte e gerar o desenvolvimento de funções psicológicas como atenção, percepção e memória. No encontro com o público, a arte traz consigo a possibilidade de desencadear mudanças, sendo vetor de desenvolvimento e aprendizagem, e isso vale tanto para o psicólogo quanto para a sua clientela. Considerando que o contato com diversas formas de arte traz elementos que podem provocar impacto nos aspectos afetivos, cognitivos, estéticos, sociais e culturais, fundamentais para a formação do psicólogo, os cursos de Psicologia poderiam encontrar formas efetivas de possibilitar aos alunos esse contato. Entretanto, assim como a Psicologia, isoladamente, não é apanágio para todos os problemas humanos, também a arte necessita de parcerias com outras áreas do conhecimento para possibilitar maior compreensão do sujeito.

Acreditamos que um encontro entre a Psicologia e a arte, como o aqui apresentado, pode contribuir para trazer à vida do futuro profissional aspectos e questões próprios da condição humana, relacionados à estética, ao respeito à diferença, ao contato com o novo e às múltiplas discussões daí decorrentes. Vivendo as mudanças trazidas pelo contato pessoal com a arte, torna-se mais fácil, para o estudante, levar essas vivências para as suas atividades profissionais. 
Silvia Maria Cintra da Silva Universidade Federal de Uberlândia Av. Pará, 1720, Bloco $2 \mathrm{C}$ - Instituto de Psicologia Campus Umuarama Uberlândia - MG - CEP 38405-320

ALBANO, A. A. O Sorriso Etrusco e a Monitora que Foi 'no Antigamente’. Folha de S.Paulo. São Paulo, agosto/setembro 2001. Folha Educação 14, p.3.

BACHELARD, G. A Poética do Devaneio. Tradução Antonio de Pádua Danesi. São Paulo: Martins Fontes, 1988.

BENCHAYA, R. Percepção do Estágio Supervisionado em Psicologia Escolar: Relatos de Estagiários e Supervisores. Dissertação de Mestrado, Universidade de São Paulo, São Paulo, 1993.

BOGDAN, R.; BIKLEN, S. Investigação Qualitativa em Educação - uma Introdução à Teoria e aos Métodos. Tradução Maria João Alvarez, Sara Bahia dos Santos e Telmo Mourinho Baptista. Portugal: Porto Editora, 1994.

BRONOWSKI, J. Arte e Conhecimento - Ver, Imaginar, Criar. Tradução Artur Lopes Cardoso. São Paulo: Martins Fontes, 1983.

BUORO, A. B. O Olhar em Construção - uma Experiência de Ensino e Aprendizagem da Arte na Sala de Aula. São Paulo: Cortez, 1996.

DUARTE JR., J. F. O Sentido dos Sentidos-a Educação (do) Sensível. Curitiba: Criar Edições, 2001.

FOUCAULT, M. Las Meninas. In As Palavras e as Coisas. Tradução Salma Tannus Muchail. São Paulo: Martins Fontes, 1995, 7. ed.

OLIVEIRA, M. K. O Pensamento de Vygotsky Como Fonte de Reflexão Sobre a Educação. Cadernos CEDES 35, 1995, pp.9-14.

OTT, R. W. Ensinando Crítica nos Museus. In Barbosa, A. M. T. B. (org.) Arte-educação: Leitura no Subsolo. São Paulo: Cortez, 1997.
RABITTI, G. À Procura da Imensão Perdida: uma Escola de Infância de Reggio Emilia. Tradução Alba Olmi. Porto Alegre: Artes Médicas, 1999.

RODARI, G. Gramática da Fantasia. Tradução Antonio Negrini. São Paulo: Summus, 1982.

SILVA, S. M. C. Arte e Educação - na Confluência das Áreas, a Formação do Psicólogo Escolar. Tese de Doutorado, Universidade Estadual de Campinas, Campinas,2002.

. Condições Sociais da Constituição do Desenho Infantil. Psicologia USP. São Paulo, v.9, n.2, 1998, pp.205-220.

SMOLKA, A. L. B. Esboço de uma Perspectiva Teórico-metodológica no Estudo de Processos de Construção de Conhecimento. In Góes, M.C.R.; Smolka, A.L.B. (org.) A Significação nos Espaços Educacionais: Interação Social e Subjetivação. Campinas, SP: Papirus,1997.

THISTLEWOOD, D. Estudos Críticos: o Museu de Arte Contemporânea e a Relevância Social. In Barbosa, A. M. T. B. (org.) Arte-educação: Leitura no Subsolo. São Paulo: Cortez, 1997.

VYGOTSKY, L. S. Psicologia Pedagógica. Tradução Paulo Bezerra. São Paulo: Martins Fontes, 2001.

Psicologia da Arte. Tradução Paulo Bezerra. São Paulo: Martins Fontes, 1999.

A Formação Social da Mente. Tradução José Cipolla Neto, Luis Silveira Menna Barreto e Solange Castro Afeche. São Paulo: Martins Fontes,1998, 2. ed.

Referências 